\title{
Effectiveness of a proteoliposome-based vaccine against salmonid rickettsial septicaemia in Oncorhynchus mykiss
}

\author{
Mario Caruffo 1,2,3, Sonia Vidal ${ }^{3}$, Leonardo Santis ${ }^{3}$, Daniela Siel ${ }^{3}$, Oliver Pérez ${ }^{4}$, Paula R. Huenchullan ${ }^{1}$ and \\ Leonardo Sáenz $3^{*}$ (I)
}

\begin{abstract}
Salmonid rickettsial septicaemia (SRS) is a contagious disease caused by Piscirickettsia salmonis, an intracellular bacterium. SRS causes an estimated economic loss of $\$ 700$ million USD to the Chilean industry annually. Vaccination and antibiotic therapy are the primary prophylactic and control measures used against SRS. Unfortunately, commercially available SRS vaccines have not been shown to have a significant effect on reducing mortality. Most vaccines contain whole inactivated bacteria which results in decreased efficacy due to the limited ability of the vaccine to evoke a celIular mediated immune response that can eliminate the pathogen or infected cells. In addition, SRS vaccine efficacy has been evaluated primarily with Salmo salar (Atlantic salmon). Vaccine studies using Oncorhynchus mykiss (rainbow trout) are scarce, despite SRS being the leading cause of infectious death for this species. In this study, we evaluate an injectable vaccine based on P. salmonis proteoliposome; describing the vaccine security profile, capacity to induce specific anti-P. salmonis IgM and gene expression of immune markers related to T CD8 cell-mediated immunity. Efficacy was determined by experimental challenge with $P$. salmonis intraperitoneally. Our findings indicate that a $P$. salmonis proteoliposome-based vaccine is able to protect $O$. mykiss against challenge with a $P$. salmonis Chilean isolate and causes a specific antibody response. The transcriptional profile suggests that the vaccine is capable of inducing cellular immunity. This study provides new insights into 0 . mykiss protection and the immune response induced by a P. salmonis proteoliposome-based vaccine.
\end{abstract}

Keywords: Salmonid rickettsial septicemia, SRS, vaccine, proteoliposome, cell membrane, Oncorhynchus mykiss

\section{Introduction}

The aquaculture industry is threatened by infectious diseases that cause severe economic losses due to low productivity. Chilean aquaculture, specifically salmon and trout farming is the largest in the world alongside Norway. Significant economic losses occur annually due to salmonid rickettsial septicaemia (SRS). SRS is a contagious disease affecting wild and cultured salmonids such

\footnotetext{
*Correspondence: leosaenz@uchile.cl

${ }^{3}$ Laboratorio de Vacunas Veterinarias, Departamento de Ciencias Animales, Universidad de Chile, Santiago, Chile

Full list of author information is available at the end of the article
}

as coho salmon (Oncorhynchus kisutch), Atlantic salmon (Salmo salar) and rainbow trout (O. mykiss) during the on-growing phase in seawater $[1,2]$. The disease is caused by Piscirickettsia salmonis a Gram negative, facultative intracellular, nonmotile, nonencapsulated, pleomorphic but usually coccoid bacterium with an approximate diameter of $0.5-1.5 \mu \mathrm{m}$ [3]. P. salmonis was originally isolated in 1989 from coho salmon in southern Chile. The disease is characterized by colonization of several organs including kidney, liver, spleen, intestine, brain, ovary, and gills $[1,4]$. SRS mainly affects the Chilean industry where annual economic losses are estimated to be $\$ 700$ million USD [3]. However, there have been reports of P. salmonis original author(s) and the source, provide a link to the Creative Commons licence, and indicate if changes were made. The images or other third party material in this article are included in the article's Creative Commons licence, unless indicated otherwise in a credit line to the material. If material is not included in the article's Creative Commons licence and your intended use is not permitted by statutory regulation or exceeds the permitted use, you will need to obtain permission directly from the copyright holder. To view a copy of this licence, visit http://creativecommons.org/licenses/by/4.0/. The Creative Commons Public Domain Dedication waiver (http://creativeco mmons.org/publicdomain/zero/1.0/) applies to the data made available in this article, unless otherwise stated in a credit line to the data. 
infections in Ireland, Norway, Canada [5, 6], and Turkey [7]. Outbreaks outside of Chile have had reduced virulence compared to those in Chile which could be the result of $P$. salmonis isolate differences and production strategies [8].

Vaccination and antibiotic therapy are the primary prophylactic and control measures used against SRS. Commercially available SRS vaccines have not significantly reduced mortality under field conditions [3]. Antibiotics have been used extensively leading to Chilean salmon farming having one of the highest rates of antibiotic consumption per ton of harvested fish in the world [9]; generating an economic and environmental problem. $90 \%$ of antibiotic use is for SRS treatment [10]. Antibiotic resistance is another serious problem. Therefore, the development of new curative or preventive therapies is necessary to reduce antibiotic usage and increase fish survival. The use of vaccination to prevent disease is used routinely in finfish aquaculture, especially in salmonids [11]. There are currently 56 salmonid vaccines registered in Chile; of which 34 contain P. salmonis antigens (SAG, December 2020) [12]. Most vaccines are administered via injection (31) with a low number of immersion (1) or oral (2) formulations. The vaccines used are mainly bacterin-based vaccines composed of $P$. salmonis whole cell inactivated with formalin or heat (30). Three of them are based on recombinant antigens and one is a live attenuated vaccine [12]. Despite the large number of available vaccines, SRS continues to be the main cause of infectious death by salmonids in Chile.

Bacterin-based vaccines are known for inducing humoral immune responses whose protective mechanism is neutralization of extracellular replicating pathogens [13]. The use of bacterin-based vaccines to immunize against extracellular bacteria has provided substantial protection against Flavobacterium columnare, Vibrio anguillarum, and Yersinia ruckerii [14, 15]. However, the efficacy of this type of vaccine against intracellular bacteria is limited due to the inability to evoke a cellular mediated immune response capable of eliminating intracellular pathogens or infected cells. The challenge for SRS vaccine development is to increase the efficacy against intracellular bacterial pathogens.

Vaccines based on bacterial proteoliposome have demonstrated an ability to induce a cellular immune response [16-20] as well as both systemic and mucosal antibody responses in mammals [21]. Proteoliposomes are made from bacterial membranes, which are solubilized through the use of detergents and cell disruption techniques such as ultrasound. Once the detergent is removed, proteoliposomes form spontaneously without damaging antigens [22]. These proteolipidic nanovesicles incorporate not only bacterial proteins but also other elements from the pathogen, such as lipopolysaccharides, bacterial cell wall or even traces of bacterial DNA, structures that have proven to have immunopotentiating and immunomodulatory effects [23]. So far, no vaccine has been developed for fish using bacterial proteoliposome as antigens. Only its use as an adjuvant has been described in an oral $A$. hydrophila bacterin adjuvanted with a proteoliposome derived microparticle that increased production of IgM in fish [22]. For these reasons, the development of a vaccine based on proteoliposomes derived from $P$. salmonis is an attractive alternative that could replace or complement other vaccines.

The aim of this work was to evaluate a new injectable vaccine formulation with proteoliposome derived from $P$. salmonis in O. mykiss. The vaccine was capable of inducing a specific immune response against $P$. salmonis and fish immunized with this formulation were effectively protected against a lethal $P$. salmonis challenge.

\section{Materials and methods \\ Fish maintenance}

Disease-free $40 \mathrm{~g}$ rainbow trout (O. mykiss) were obtained from a local aquaculture facility and maintained at Quillaipe experimental center (Puerto Montt, Chile). During acclimatization (14 days) and immunization (71 days) fish were maintained in $1 \mathrm{~m}^{3}$ tanks at a density of $11 \mathrm{~kg} / \mathrm{m}^{3}$ in fresh water with an exchange rate of $0.8-1$ $\mathrm{m}^{3} / \mathrm{h}$. Water salinity was gradually increased to $\sim 32 \mathrm{ppt}$ (parts per thousand) previous to challenge. Water conditions during acclimatization and immunization were: $12 \pm 1{ }^{\circ} \mathrm{C}$ and oxygen saturation was $80-110 \%$. Fish were fed ad libitum four times a day (EWOS micro 50 and 100, EWOS, Chile).

\section{Preparation of vaccine formulations and vaccination}

The vaccine is based on a bacterial proteoliposome generated from $P$. salmonis (LF-89, field strain) bacterial membranes. Bacteria were grown in a cell free medium, SFX-Insect (HyClone) with constant agitation for 14 days at $18{ }^{\circ} \mathrm{C}$. Bacterial pellets were washed with phosphate buffer saline (PBS) and then frozen at $-80^{\circ} \mathrm{C}$. Each gram of pellet was resuspended in $25 \mathrm{~mL}$ of lysis buffer $\left(\mathrm{Na}_{2} \mathrm{HPO}_{4} 20 \mathrm{mM}, \mathrm{NaCl} 0.5 \mathrm{M}, \mathrm{pH} 7.4\right.$ and sterilized by filtration) with $2 \mathrm{~g}$ of sterile zirconium silicate beads $0.1 \mathrm{~mm}\left(\right.$ BioSpec $\left.^{\circledR}\right)$ and sonicated at $100 \%$ capacity (Ultrasonic Processor UP400S, Hielscher). Supernatant was recovered and centrifuged again at $20000 \mathrm{~g}$ for $15 \mathrm{~min}$. The pellet was resuspended in membrane solubilization buffer (Tris- $\mathrm{HCl} 20 \mathrm{mM}, \mathrm{KCl} 25 \mathrm{mM}$, Sodium deoxycholate $1.5 \%(\mathrm{w} / \mathrm{v})$ at $\mathrm{pH} 10$ and filtered $0.2 \mu \mathrm{m})$ and incubated at $100 \mathrm{RPM}$ at $20{ }^{\circ} \mathrm{C}$ overnight (ON). The solution was centrifuged at $500 \mathrm{~g}$ for $5 \mathrm{~min}$ and supernatant was incubated in Bio-Beads (BioRad) following 
manufacturer instructions and resuspended in saline solution $(10 \mathrm{~mL}$ saline/1 g pellet). The vaccine formulation was made of $10 \mu \mathrm{g}$ of $P$. salmonis proteoliposome, emulsified with one of two adjuvants per manufacturer instructions: Montanide ISA 760 VG (vaccine 1) or ISA 763 A VG (vaccine 2) (Seppic, France) a water-in-polymer and a water-in-oil, respectively.

\section{Size estimation and measure of the Zeta potential}

The Zeta potential of proteoliposome was measured using a Zeta potential analyzer (ZetaPlus, Brookhaven Instruments). Measurements were determined at $25{ }^{\circ} \mathrm{C}$ in an electric field of $15.62 \mathrm{~V} / \mathrm{cm}$. The size and polydispersity index were determined by light scattering using a multi-angle particle sizing option (ZetaPlus, Brookhaven Instruments). A stock solution of proteoliposome $(1.5 \mathrm{mg} / \mathrm{mL}$ in ultrapure water) was used for both Zeta potential and particle size measurements. $50 \mu \mathrm{L}$ of proteoliposome was mixed $5 \mathrm{~mL}$ of bi-filtered $\mathrm{KCl}(1 \mathrm{mM}$ in ultrapure water; $\mathrm{pH}$ 6.8-7.0).

\section{Fish vaccination}

Fish were anaesthetized with benzocaine (Kalmagin $20 \%$, Centrovet) and vaccinated by intra-peritoneal (i.p.) injection $(100 \mu \mathrm{L}$ per fish, $10 \mu \mathrm{g}$ of total protein of $P$. salmonis proteoliposome) and control groups were injected i.p. with $100 \mu \mathrm{L}$ of sterile saline. After 300 degree-days (DD, close to 25 days) a second immunization dose was given. This $P$. salmonis proteoliposome based vaccine was developed by the Laboratory of Veterinary Vaccines, Universidad de Chile.

\section{Safety and adverse effects of vaccine evaluations}

To evaluate vaccine safety 20 fish per group were sampled 300 DD post-second immunization and euthanized by overdose of benzocaine. As a measure of overall fish fitness, the weight and fork length were recorded and Fulton's Condition Factor was calculated ( $\mathrm{K}=$ Weight/ Lenghth $^{3}$ ) [24]. A post-mortem gross pathology examination of the intraperitoneal cavity was conducted and scored according to gross pathological score systems: Speilberg score according to Midtlyng et al. [25].

\section{Experimental design and sampling}

Before the challenge experiment was performed, the median lethal dose $\left(\mathrm{LD}_{50}\right)$ of $P$. salmonis (LF-89 type) was determined. P. salmonis (LF-89) was provided by ADL Diagnostic Chile Ltda. Four dilutions were assessed from a stock concentration of $1 \times 10^{8.5}$ tissue culture infective dose $50 \%$ per $\mathrm{mL}\left(\mathrm{TCID}_{50} / \mathrm{mL}\right.$, determined through the Karber-Spearman method), from which four dilutions were made by a factor of 10 (1:10 to 1:10 000). These dilutions plus a control made of L15 media (Leibovitz,
Invitrogen) were administered by i.p. injection in $200 \mu \mathrm{L}$. Fish were distributed in five $350 \mathrm{~L}$ tanks ( $n=30 \mathrm{fish} / \operatorname{tank}$ ) at a density of $9 \mathrm{~kg} / \mathrm{m}^{3}$ (seawater). Fish were monitored daily for 25 days and mortalities recorded. From these results the challenge dose was determined to be 1:10 000 (Additional file 1).

The challenge was conducted at Quillaipe experimental center (Puerto Montt, Chile) as shown in Figure 1A. Forty fish per condition (vaccine 1, vaccine 2 and control) were stocked in $720 \mathrm{~L}$ tanks at a density of $24 \mathrm{~kg} / \mathrm{m}^{3}$ in seawater. Fish from each treatment group were in each tank. All fish were marked with a PIT tag (Passive Integrated Transponder, ID-100 microtransponder, Trovan) to identify treatment groups for sampling and mortality analysis. Bacterial challenge was performed in triplicate by intraperitoneal inoculation.

Five fish per treatment were anesthetized for sampling in pre-vaccination, after the first immunization and after the second immunization (Figure 1A). Blood samples were taken from the caudal vein with a $3 \mathrm{~mL}$ syringe and stored at $4{ }^{\circ} \mathrm{C}$ for $24 \mathrm{~h}$ and then centrifuged for $10 \mathrm{~min}$ at $6000 \mathrm{~g}$. Serum samples were stored at $-20^{\circ} \mathrm{C}$ until use to evaluate antibody production. After blood samples fish were euthanized by overdose of benzocaine and anterior kidney samples were taken to address gene expression. Sampling was performed just previous to experimental challenge to avoid additional stress during the course of the challenge. Mortality was recorded daily until day 25 post-challenge and confirmed by qPCR analysis according to Karatas et al. [26].

\section{Antibody ELISA}

Nunc Polysorb plates were activated with $40 \mu \mathrm{g} / \mathrm{mL}$ of total protein extracts from $P$. salmonis (LF-89, field strain) in bicarbonate buffer $\left(\mathrm{NaHCO}_{3} 0.15 \mathrm{M}, \mathrm{Na}_{2} \mathrm{CO}_{3}\right.$ $0.035 \mathrm{M}, \mathrm{pH} 9.6$ ) and incubated at $4{ }^{\circ} \mathrm{C}$ ON. Unbound antigens were removed by washing twice with PBST (PBS and Triton X-100 0.02\% (v/v)). The plates were blocked with PBS containing $5 \%$ skim milk at $4{ }^{\circ} \mathrm{C} \mathrm{ON}$ and washed twice with PBST. One hundred $\mu \mathrm{L}$ of blood serum diluted 1:100 (PBS and Triton X-100 0.02\% (v/v)) were added and incubated for $2 \mathrm{~h}$ at $37^{\circ} \mathrm{C}$, then washed five times and incubated with monoclonal mouse antisalmon IgM (Ango ${ }^{\circledR}$ FM190AZ5) diluted 1:1000 in blocking solution at $4{ }^{\circ} \mathrm{C}$ ON. Then, plates were washed again and incubated with horseradish peroxidase conjugated donkey anti-mouse IgG (Rockland, 610703002) diluted 1:10 000 in PBST. Serum antibody levels were determined using 3,3'5,5'-tetramethylbenzidine as a chromogenic substrate and $\mathrm{H} 2 \mathrm{SO} 42 \mathrm{~N}$ was used to stop the reaction. Pooled serum obtained from $P$. salmonis experimentally infected fish was used as a positive control. The Absorbance value for each sample was measured at $450 \mathrm{~nm}$. All 


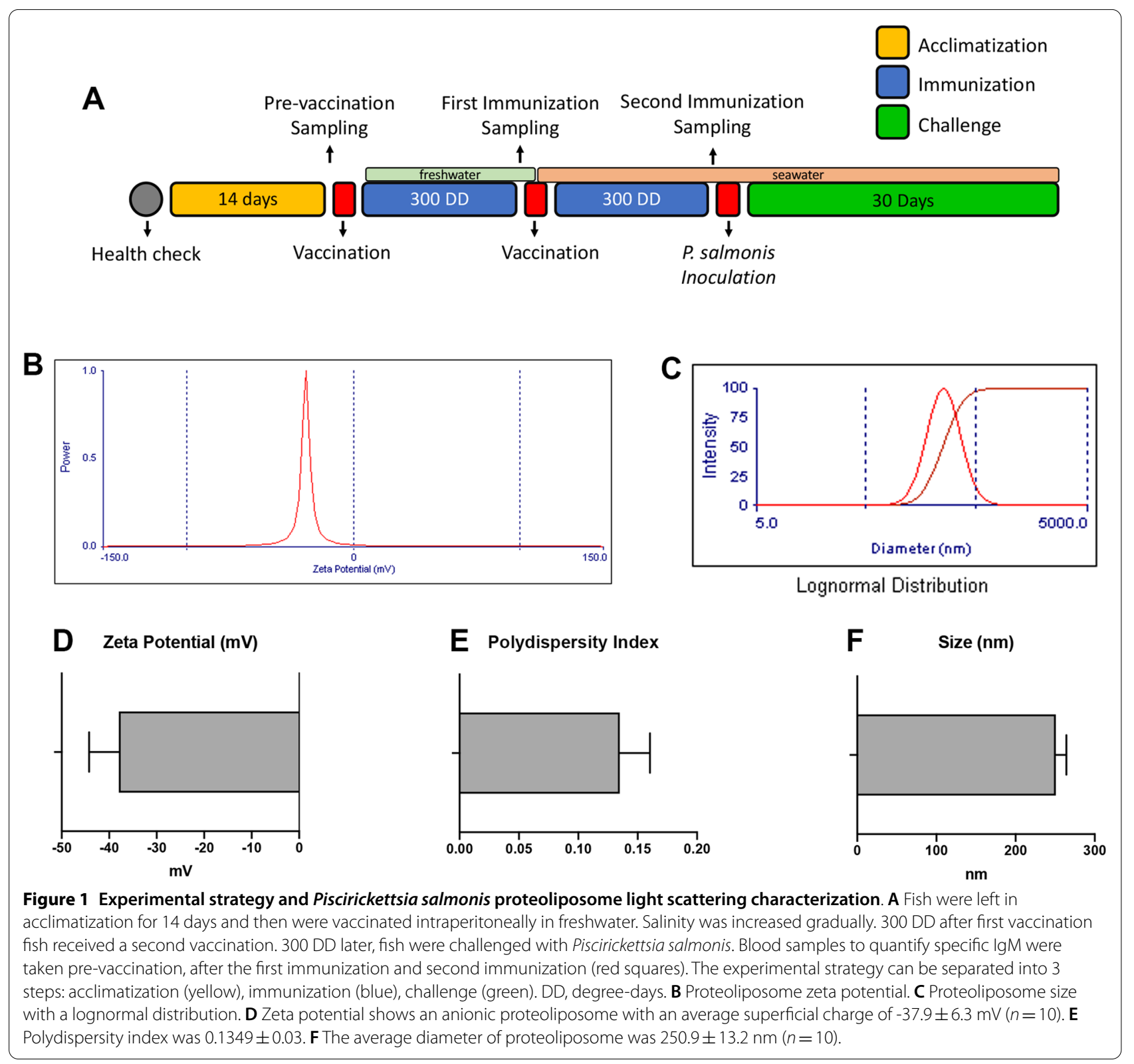

samples were analyzed in triplicate with negative and positive controls.

\section{Gene expression analysis of immune markers}

We evaluated gene expression of some immune markers in fish at 600 DD post first vaccination in order to evaluate the impact of the vaccine prior to bacterial challenge. Reactions were carried out on a real-time PCR System (Applied Biosystems) using the Terra qPCR Direct TB Green Premix kit (Takara). Total RNA was extracted from $100 \mathrm{mg}$ of head kidney tissue using TRIZOL reagent (Invitrogen), and incubated for $30 \mathrm{~min}$ at $37{ }^{\circ} \mathrm{C}$ with 20 units of RQ1 RNase-Free DNase (Promega) to remove residual genomic DNA. RNA was purified using the RNeasy mini kit (Qiagen) and RNA concentration was determined as described above. Two $\mu \mathrm{g}$ of total RNA was used for reverse transcription reactions to synthesize single strand cDNA using SuperScript II Reverse Transcriptase and Oligo-dT primers (ThermoFisher Scientific), according to standard procedures. cDNA was diluted to $100 \mathrm{ng}$ and used as the template for qPCR, with primers designed against the following immune markers: Major histocompatibility complex I ( $m h c 1)$, tumor necrosis factor alpha $(\operatorname{tnf} \alpha)$, cluster of differentiation $8 \mathrm{a}(c d 8 \alpha)$, interferon gamma (ifn $)$ ), and T cell receptor beta 1 (trbI) as previously published [27-30]. The thermal profile 
used was $95{ }^{\circ} \mathrm{C} 10 \mathrm{~min}, 40 \times\left(95^{\circ} \mathrm{C} \times 30 \mathrm{~s}, 60{ }^{\circ} \mathrm{C} \times 30 \mathrm{~s}\right.$, $\left.72{ }^{\circ} \mathrm{C} \times 30 \mathrm{~s}\right)$. Relative expression of mRNA was calculated using $2-\Delta \Delta C T$ adjusted to primer efficiency [31]. Elongation factor 1-alpha (EF1a) was used as housekeeping gene. Primers used are listed in Additional file 2.

\section{Statistical analysis}

Statistical analysis was performed using GraphPad Prism 8 (Graphpad Software, Inc). Fulton's condition factor was calculated as described above and differences were analyzed using analysis of variance (ANOVA) followed by a Tukey's multiple comparisons test. Data obtained from gross pathological scoring for Speilberg score, and gene expression was analyzed by Kruskal-Wallis test followed by a Dunn's post-test for multiple comparisons. Survival curves were analyzed using Kaplan-Meier and group differences were analyzed using Log-rank test. To assess the effectiveness of formulations the relative percent survival (RPS), absolute risk reduction (ARR), and number of animals necessary to treat (NNT) were calculated (all formulas used are described in Additional file 3). Differences in antibodies were calculated using ANOVA and Dunnett's multiple comparison test. $p \leq 0.05$ was considered significant and all experiments were performed at least in triplicate.

\section{Results}

Characterization of Piscirickettsia salmonis proteoliposome Proteoliposomes generated from $P$. salmonis membranes were characterized in terms of size and charge. The average diameter of $P$. salmonis proteoliposomes was shown by dynamic light scattering to be $250.9 \pm 13.2 \mathrm{~nm}(n=10)$ with a low polydispersity index (PDI) of $0.1349 \pm 0.03$; indicating the degree of dispersion of sizes. When PDI is 0 all particles are the same size and when the PDI is 1 all particles are different sizes. The zeta-potential, which indicates the charge present in the interface of the particle and the aqueous medium was $-37.9 \pm 6.3 \mathrm{mV}(n=10)$ (Figures 1B-F).

\section{Vaccine formulations are safe and do not affect fish weight gain}

During the immunization period there were no mortalities. Fish among the different treatment groups were evaluated using Fulton's condition factor previous to bacterial challenge to evaluate if the vaccines influenced the fitness or condition of fish. Vaccinated fish had no statistically significant differences in Fulton's condition factor compared to control ( $p \geq 0.05$, ANOVA, Tukey's multiple comparisons) (Figure 2A). Minimal adverse effects were registered in vaccinated fish during the necropsy and none of the vaccinated groups showed more than 2 points in Speilberg Index (0-6) (vaccine 1: $0.7 \pm 0.5$; vaccine 2: $0.75 \pm 0.6$; control: $0.55 \pm 0.5)$; no statistically significant differences were observed between treatments and control ( $p \geq 0.05$; Kruskal-Wallis, Dunn's multiple comparison) (Figure 2B). Therefore, we can conclude that the vaccines were safe under these experimental conditions.

\section{Piscirickettsia salmonis proteoliposome vaccine induces immunity against $P$. salmonis and modulates gene expression of immunity markers}

The ability of the vaccines to induce $P$. salmonis-specific IgM in serum was determined by ELISA. No specific antibodies were detected before vaccination or in
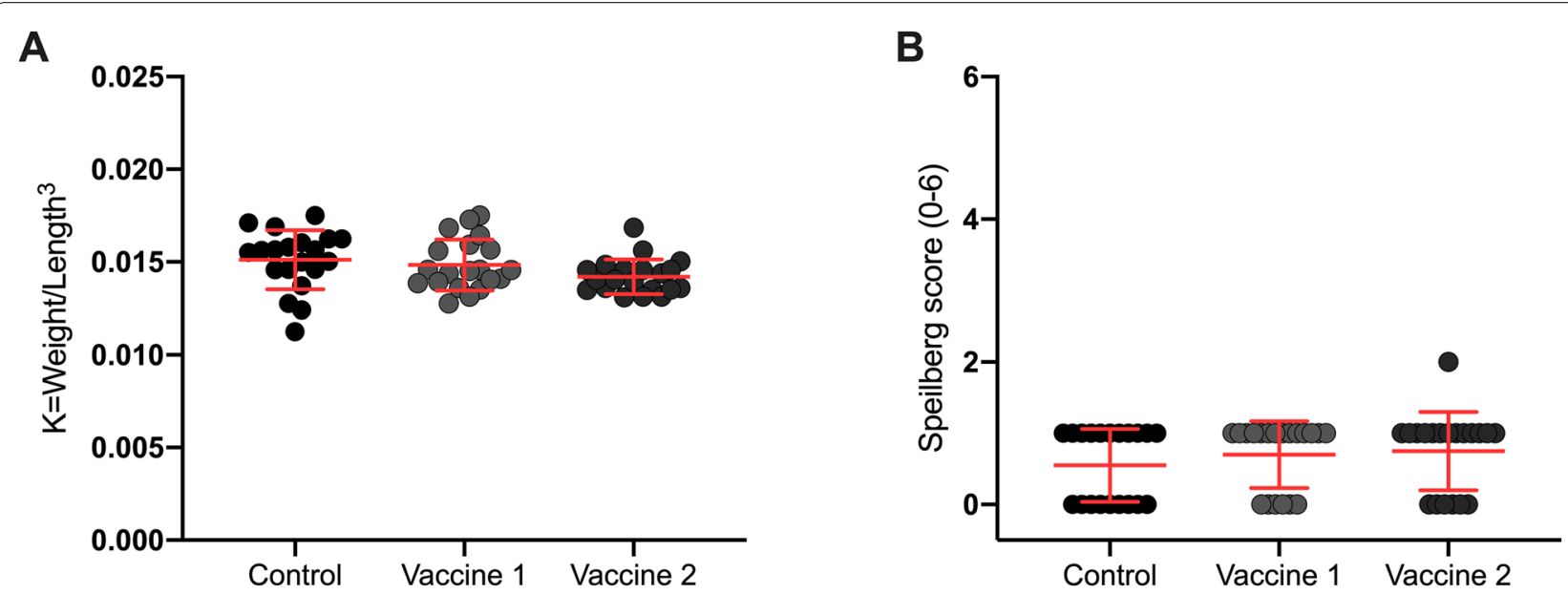

Figure 2 Safety and adverse effects vaccine evaluation. A Fulton's condition factor, B Speilberg score. Values are represented as dot-plots with mean \pm standard deviation. Vaccine 1: $10 \mu \mathrm{g}$ total protein of P. salmonis proteoliposome emulsified with Montanide ISA 760 VG, Vaccine 2: $10 \mu \mathrm{g}$ total protein of $P$. salmonis proteoliposome emulsified with ISA 763 A VG (Seppic, France). 
placebo vaccinated controls. Both vaccines were able to induce a specific anti-P. salmonis response (Figure 3A). Specific IgM induced by vaccine 1 was detected earlier than vaccine 2 , showing significant differences in relation to the control group at $300 \mathrm{DD}$ post-vaccination (first immunization sampling) $(p \leq 0.001)$. Higher antibody levels were detected at $600 \mathrm{DD}$ post-vaccination (second immunization sampling) for both formulations, showing significant differences in the induction of specific antibodies in relation to the control group (vaccine $1, p \leq 0.05$

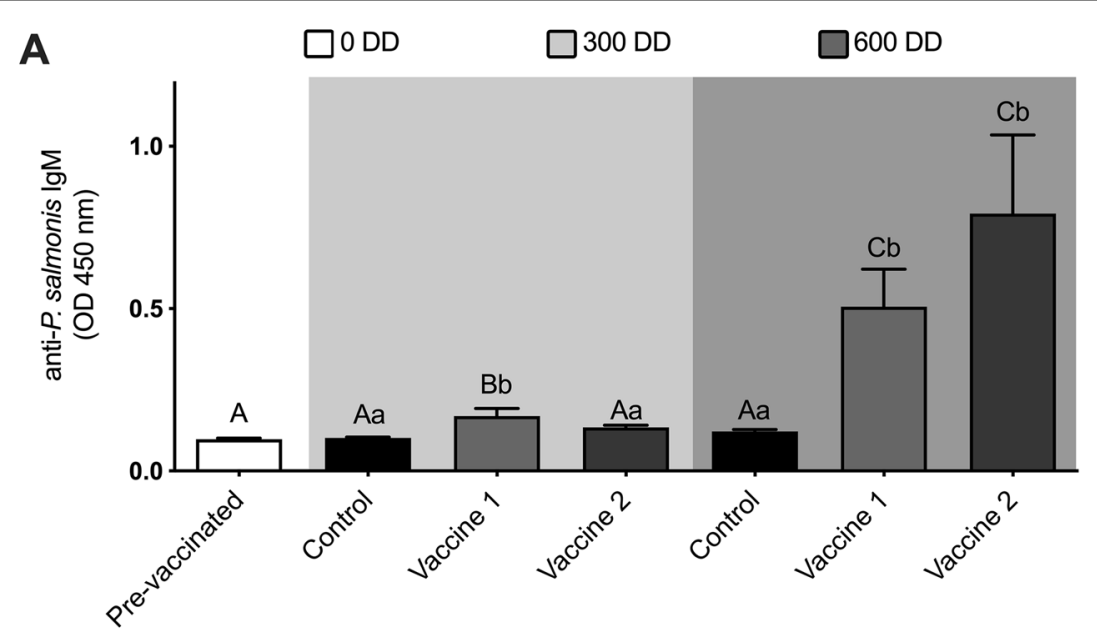

B
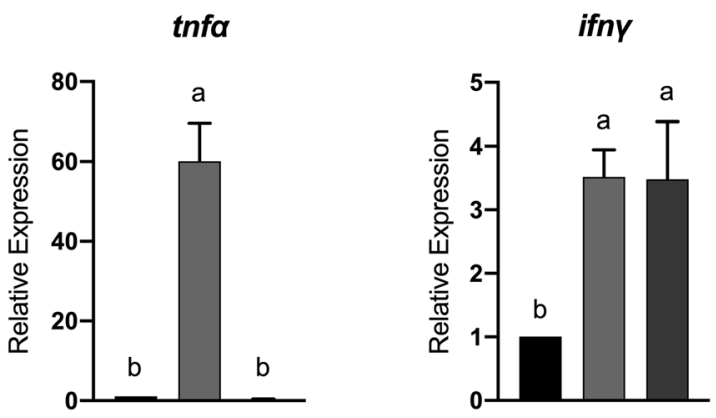

mhc1
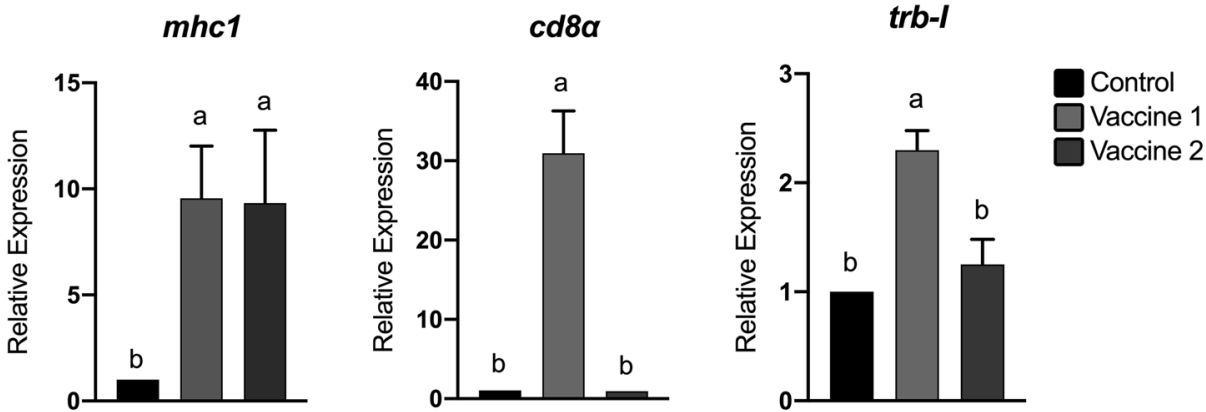

Figure 3 Effect of vaccines on the level of serum specific anti-P. salmonis IgM and gene expression of cell response immunity markers A The fish were intraperitoneally immunized with two formulations (vaccine 1 or vaccine 2) or a control (injected intraperitoneally with $100 \mu \mathrm{L}$ of sterile saline). Piscirickettsia salmonis specific IgM were measured by ELISA. The data are mean \pm SD of 5 fish per treatment at each sampling point (pre-vaccination, first immunization, second immunization). ANOVA and subsequent Tukey's multiple comparisons test. Different capital letters indicate significant differences $(p \leq 0.05)$ between sampling points and lowercase letter indicate significant differences $(p \leq 0.05)$ within the sampling point. B Expression of cellular immune response markers analyzed by qPCR. Tumor necrosis factor alpha (tnfa), interferon gamma (ifn $\mathbf{\text { ) }}$, major histocompatibility complex I ( $m$ hc1), cluster of differentiation 8 a (cd8a), T cell receptor beta 1 (trb-l). The results are the mean \pm SEM of 5 individuals, Kruskal-Wallis test followed by a Dunn's post-test. Different lowercase letters indicate significant differences $(p \leq 0.05)$. 
and vaccine $2, p \leq 0.001)$. No difference between the vaccines were detected at 600 DD. Significant increases in specific IgM levels were observed for vaccine 1 and vaccine 2 (four and six-fold compared to control and prevaccination samples); confirming that a proteoliposome based vaccine can induce an immune response in $O$. mykiss.

The relative expression of some immune markers at 600 DD post-vaccination was measured to determine the ability of the vaccines to induce a cellular immune response. Transcripts were grouped as innate response $(t n f \alpha, i f n \gamma)$ and cell-mediated immunity markers ( $m h c 1$, $c d 8 \alpha, \operatorname{trb}-1)$. The transcriptional profile for vaccine 1 showed all transcripts were upregulated compared to control; where the transcriptional profile for vaccine 2 showed increases for $m h c 1$ and ifny only (Figure 3B).

\section{Piscirickettsia salmonis proteoliposome vaccine protects against challenge}

The efficacy of the vaccines was determined by challenging fish at $300 \mathrm{DD}$ post-second immunization with a lethal dose of $P$. salmonis by i.p. inoculation, previously determined by the $\mathrm{LD}_{50}$ challenge experiment (Additional file 1). Mortality was monitored on a daily basis. Both vaccines conferred significant protection compared to the non-immunized control (Log-rank test, $p \leq 0.0001$ ). Vaccine 1 had a better final survival percentage than vaccine 2 (57.5 and $37.5 \%$ respectively, Log-rank test, $p \leq 0.0010$ ) (Figure 4). The relative percentage survival (RPS) and the absolute risk reduction (ARR) were calculated at the end of the trial. The RPS and ARR estimate the reduction of risk of death by $P$. salmonis in vaccinated vs. non vaccinated fish (in relative terms for RPS and in absolute terms for ARR). We also calculated the number of animals necessary to treat (NNT), a parameter that indicates the number of animals that must receive the treatment (vaccine) in order for one animal to survive in the evaluated time interval ( 25 days). Vaccine 1 had an RPS of $46.06 \%$, an ARR of $36.31 \%$ and NNT $=3$; while vaccine 2 had an RPS of $20.68 \%$, an ARR of $16.31 \%$ and NNT $=7$. The results indicate that both vaccines are able to protect fish, but vaccine 1 showed better efficacy than vaccine 2 (Additional file 3 ).

\section{Discussion}

The strategy of developing proteoliposome from a bacterial substrate has been explored primarily in murine models with projected use in humans [20,32-34]. In recent years there has been an increase in publications related to the use of liposomes, and micro- and nanoparticles for the development of new vaccines in aquaculture [35-37]. The use of proteoliposomes generated

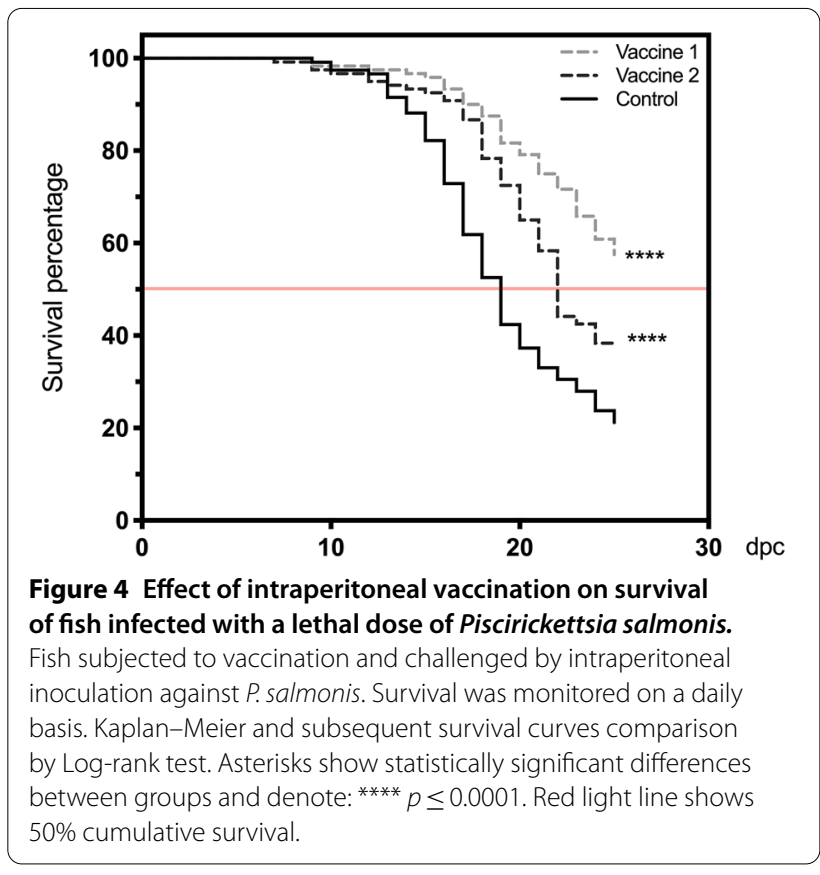

from $P$. salmonis membranes is a novel approach to generate a vaccine without antigen degradation due to heat- and formalin-inactivated bacteria. Proteoliposome formulations contain microbial- or pathogenassociated molecular patterns (MAMPs or PAMPs) that act as immunopotentiators and also exerts delivery system ability as well [23]. The use of proteoliposomes as vaccines for salmonids has not been addressed until now.

The physicochemical characteristics that can affect the performance of a vaccine are size, shape, surface load, hydrophobic and hydrophilic capacity, as well as the ability to interact with host receptors [38]. Many of these factors are related to the ability to interact with antigen-presenting cells (APCs) and the correct induction of a protective immune response [39]. While there is not much literature regarding particle size and immune response in teleosts, size is described as an important factor; APCs and B-lymphocytes are capable of phagocytizing particles of at least $1 \mu \mathrm{m}$ [40]. In turbot (Scophtalmus maximus) it has been determined that the maximum particle size to reach a secondary lymphoid organ after an intraperitoneal inoculation is less than $4 \mu \mathrm{m}$ [41]. This information is relevant since if the antigen is not capable of reaching secondary lymphoid organs in sufficient quantities it will be ignored immunologically [42]. The size obtained during the $P$. salmonis proteoliposomes characterization was less than $1 \mu \mathrm{m}$ on average $(250.9 \pm 13.2 \mathrm{~nm})$ and could be 
classified as nanoparticles [36]; making them small enough to reach secondary lymphoid organs in teleosts.

Results obtained when quantifying the zeta potential are directly related to the source of the lipid used [43]. In this case the membranes were obtained directly from $P$. salmonis presenting anionic charge on the surface with zeta potential values below $-30 \mathrm{mV}(-37.9 \pm 6.3 \mathrm{mV})$. This indicates that the vaccines present good stability and dispersion [36]. Ionized liposomes (either positively or negatively) have a better adjuvant performance than neutral ones [44]. The internalization of ionized particles by APCs increases up to 1.3 times in relation to neutral ones [45] and it has been described that scavenger-type receptors present in APC are able to recognize anionic particles, facilitating their internalization [46]. Finally, some studies have shown that anionic liposomes induce a Th1 biased cellular immune response: a desirable characteristic for a vaccine designed against an intracellular pathogen like P. salmonis [44, 47]. Although much of this information comes from studies conducted in mammals, results obtained in trout macrophages and zebrafish using anionic liposomes have shown increased internalization $[48,49]$, suggesting a conserved mechanism.

There are safety concerns when using injectable vaccines based on oil adjuvants, since adverse effects can occur. No reduction in growth was observed in the present study at 300 DD post-immunization using Fulton's condition factor as a measure; although there are studies describing growth reduction with oil-based vaccines in salmonids [50, 51]. Macroscopic observations of vaccinated and control fish revealed mild changes in vaccinated groups during post-mortem examination without significant differences in relation to control using Speilberg index as an evaluation tool to address adverse effects. Therefore, we can say that both vaccines are safe.

Bacterin based vaccines will, in general, elicit an immune response biased toward humoral immunity with a lesser induction of cell-mediated immune response [52]. Antibodies will attach to surface antigens of the pathogen resulting in opsonization and phagocytosis [53, 54]. P. salmonis is an intracellular pathogen, therefore these functions are useful during early stages of infection, from port of entry (gills, skin, and gut) and transport to primary or secondary multiplication sites [55]. There is no information on how $P$. salmonis disseminates in the host. If an extracellular pathway is not used, the usefulness of antibodies in limiting the infection would be reduced. It is known that there is a correlation between antibody titers and protection against mortality in $P$. salmonis infection $[55,56]$. Consequently the induction of antibodies is a desired effect. Immune response elicited in terms of specific anti-P. salmonis IgM in vaccinated groups showed a significant induction at 300 and 600 DD after first immunization for vaccine 1 compared to control. Vaccine 2 only showed a significant induction at 600 DD after first immunization compared to control. The second immunization enhance the magnitude of antibody induction showing a 4 and sixfold anti-P. salmonis IgM compared to control without significant differences between vaccines (Figure 3A). Injected anti-SRS vaccines are able to induce specific IgM antibodies. When the concentration of antibodies is below $2000 \mathrm{pg} / \mathrm{mL}$ in farmed salmonids a window of susceptibility to SRS infection was observed, suggesting a close association between antibody levels and protection [56].

Teleosts have a specific cell-mediated immunity characterized by antigen presentation by MHC-I to CD8 T lymphocytes [56-59]. Therefore, we evaluated the gene expression of markers associated with the stimulation of a cellular immune response using head kidney. To analyze the inflammatory response, we measured the expression of $\operatorname{tnf\alpha }$. $\operatorname{tnf\alpha }$ was strongly upregulated in fish receiving vaccine 1 , but no induction was observed in vaccine 2 . Fish immunized with vaccine 1 showed upregulation of $m h c 1, c d 8 a$, ifn $\gamma$, and trb-I suggesting that vaccine 1 is promoting a CD8 $\mathrm{T}$ cell mediated response. Vaccine 2 induced an upregulation of a reduced number of transcripts different from control, when compared to vaccine 1 . Unlike the vaccines developed for this study which are proteoliposome based, $P$. salmonis bacterin based vaccines in Salmo salar, induce an upregulation of $m h c 1$ but downregulation of $c d 8$ suggesting that bacterin based vaccines support a CD4 T cell response and are unable to induce a CD8 $\mathrm{T}$ cell immune response [60]. Transcriptional results using the vaccines from this study suggest that a cellular response is being induced by the $P$. salmonis proteoliposome based vaccine.

Efficacy of vaccines against SRS are variable and depend on the type of vaccine, route of immunization and the lethality of $P$. salmonis strain used in the challenge [55]. The majority of studies available use Salmo salar or $O$. kisutch and showed RPS rates ranging from 10 to $90 \%[4,61-66]$. There is only one study that evaluates vaccine efficacy in O. mykiss. Smith et al., determined the efficacy of an injectable $P$. salmonis vaccine made from formalin-killed bacterin. The cumulative mortality was lower than nonvaccinated fish. However, lethality of the $P$. salmonis challenge strain was not strong enough because mortality in the infected nonvaccinated group was low (20\%) [67].

In this study, the first challenged fish died 7 days postchallenge (DPC), mortality then increased in all groups from day 10 onwards. These results are in agreement with the previously reported incubation period for P. salmonis LF89 i.p. infection of 10-20 days [60, 65]. Cumulative mortality of the control group during the 
challenge was $78.8 \%$. The lowest mortality during LD50 determination was $96.7 \%$, indicating the high virulence of the bacterial isolate used in this study. Both vaccine formulations successfully conferred protection against SRS, as shown by the survival curve analysis (vaccine $1, p \leq 0.001$; vaccine $2, p \leq 0.0001$ ). The better cellular immune response profile exhibited by vaccine 1 may explain why vaccine 1 provided better protection than vaccine 2 . It is possible that the survival percentages for vaccine $1(57.5 \%)$ and vaccine $2(37.5 \%)$ are underestimated due to the lethality of the $P$. salmonis challenge and the inoculation route used.

Results obtained in the current study demonstrate that immunization with $P$. salmonis proteoliposomes induces a significant protection against challenge with a lethal $P$. salmonis isolate and is able to induce specific anti-P. salmonis IgM after a second dose with a transcriptional profile that suggests a CD8 $\mathrm{T}$ cell-mediated immunity. Although this first prototype shows promising results, survival due to the vaccine could be improved with the addition of recombinant antigens or by increasing the antigen concentration. Future efforts will focus on increasing the efficacy of the vaccine formulation as well as further evaluation of the transcriptional profiles of the cellular response to vaccination. This is only the second work published evaluating the efficacy of a $P$. salmonis vaccine on $O$. mykiss. SRS is the leading cause of death in trout farming, therefore further study is important. The generation of proteoliposomes to produce antigens for vaccines is potentially applicable to other pathogens important to fish farming. It is also possible to include antigens from other pathogens of interest to create multivalent vaccines.

\begin{abstract}
Abbreviations
SRS: salmonid rickettsial septicaemia; IgM: immunoglobulin M; T CD8: CD8+T cells; SAG: Servicio Agrícola Ganadero; DD: degree days; ON: overnight; mhc1: major histocompatibility complex I; tnfa: tumor necrosis factor alpha; cd8a: cluster of differentiation 8a; ifny: interferon gamma; trb-l: T cell receptor beta 1; EF1a:T cell receptor beta 1; RPS: Relative percent survival; ARR: absolute risk reduction; NNT: number of animals necessary to treat; PDI: polydispersity index; i.p: intra-peritoneal.
\end{abstract}

\section{Supplementary Information}

The online version contains supplementary material available at https://doi. org/10.1186/s13567-021-00982-2.

Additional file 1: Cumulative mortality (\%) in Oncorhynchus mykiss after Piscirickettsia salmonis challenge, LD50 determination. Dilutions used in the challenge 1/10,1/100,1/1000,1/10 000.

Additional file 2: List of primers used for gene expression studies (previously published).

Additional file 3: Efficacy indicators for $P$. salmonis vaccines and mathematical formulas.

\section{Acknowledgements}

We would like to thank Susan Cleveland for editing and revising the English grammar, Dr. Paulo Palacios and Salmones Antártica for their support. Mario Caruffo acknowledges ANID FONDECYT grant 3180675 and Giuseppe Caruffo for their tireless assistance during this study.

\section{Authors' contributions}

MC, OP, LS: Conceptualization; MC, SV: Methodology; MC, SV, OP, LS, DS: Investigation; MC: Writing_Original Draft; MC, SV, OP, LS: Writing- Reviewing and Editing; PR: Funding acquisition; PR: Project administration. All authors read and approved the final manuscript.

\section{Funding}

This work was supported by the Chilean Economic Development Agency (CORFO) 15ITE2-49472.

\section{Availability of data and materials}

The datasets during and/or analyzed during the current study are available from the corresponding author on reasonable request.

\section{Declarations}

\section{Ethics approval and consent to participate}

All the experiments regarding fish were performed in accordance with the National Institutes of Health guide for the care and use of Laboratory animals (NIH Publications No. 8023, revised 1978) and in accordance with Chilean legislation for animal experimentation under the manual "Bioethical aspects of animal experimentation" issued by the National Commission of Scientific and Technological Research (CONICYT). All animal experimental protocols were revised and approved by CICUA-UChile (2017/15ITE249472).

\section{Competing interests}

The authors declare that they have no competing interests.

\section{Author details}

${ }^{1}$ NGEN LAB S.A, Santiago, Chile. ${ }^{2}$ Escuela de Biotecnología, Facultad de Ciencias, Universidad Santo Tomás, Santiago, Chile. ${ }^{3}$ Laboratorio de Vacunas Veterinarias, Departamento de Ciencias Animales, Universidad de Chile, Santiago, Chile. "Instituto de Ciencias Básicas Y Preclínicas "Victoria de Girón", Universidad de Ciencias Médicas de La Habana, Havana, Cuba.

Received: 9 April 2021 Accepted: 12 July 2021

Published online: 23 August 2021

\section{References}

1. Fryer JL, Lannan CN, Giovannoni SJ, Wood ND (1992) Piscirickettsia salmonis gen. nov., sp. nov., the causative agent of an epizootic disease in salmonid fishes. Int J Syst Bacteriol 42:120-126. https://doi.org/10.1099/ $00207713-42-1-120$

2. Gaggero A, Castro H, Sandino AM (1995) First isolation of Piscirickettsia salmonis from coho salmon, Oncorhynchus kisutch (Walbaum), and rainbow trout, Oncorhynchus mykiss (Walbaum), during the freshwater stage of their life cycle. J Fish Dis 18:277-280. https://doi.org/10.1111/j.1365-2761. 1995.tb00303.x

3. Maisey K, Montero R, Christodoulides M (2017) Vaccines for piscirickettsiosis (salmonid rickettsial septicaemia, SRS): the Chile perspective. Expert Rev Vaccines 16:215-228. https://doi.org/10.1080/14760584.2017.12444 83

4. Wilhelm V, Miquel A, Burzio LO, Rosemblatt M, Engel E, Valenzuela S, Parada G, Valenzuela PDT (2006) A vaccine against the salmonid pathogen Piscirickettsia salmonis based on recombinant proteins. Vaccine 24:5083-5091. https://doi.org/10.1016/j.vaccine.2006.03.027

5. Jones SRM, Frederick Markham RJ, Groman DB, Roland Cusack R (1998) Virulence and antigenic characteristics of a cultured Rickettsiales-like organism isolated from farmed Atlantic salmon Salmo salar in eastern Canada. Dis Aquat Organ 33:25-31. https://doi.org/10.3354/dao033025

6. Olsen AB, Melby HP, Speilberg L, Evensen Ø, Håstein T (1997) Piscirickettsia salmonis infection in Atlantic salmon Salmo salar in 
Norway —epidemiological, pathological and microbiological findings. Dis Aquat Organ 31:35-48. https://doi.org/10.3354/dao031035

7. Öztürk RÇ, Altinok I (2014) Bacterial and viral fish diseases in Turkey. Turkish J Fish Aquat Sci 14:275-297

8. House ML, Bartholomew JL, Winton JR, Fryer JL (1999) Relative virulence of three isolates of Piscirickettsia salmonis for coho salmon Oncorhynchus kisutch. Dis Aquat Organ 35:107-113. https://doi.org/10.3354/dao035107

9. Miranda CD, Godoy FA, Lee MR (2018) Current status of the use of antibiotics and the antimicrobial resistance in the chilean salmon farms. Front Microbiol 9:1284

10. Henríquez P, Kaiser M, Bohle H, Bustos P, Mancilla M (2016) Comprehensive antibiotic susceptibility profiling of Chilean Piscirickettsia salmonis field isolates. J Fish Dis 39:441-448. https://doi.org/10.1111/jfd.12427

11. Adams A (2019) Progress, challenges and opportunities in fish vaccine development. Fish Shellfish Immunol 90:210-214. https://doi.org/10. 1016/j.fsi.2019.04.066

12. Registro provisional de productos inmunológicos de uso en salmónidos (SAG). http://www.sag.cl/sites/default/files/lista_salmonidos_registro_ provisional_0.pdf. Accessed 20 Jan 2021

13. Munang'andu HM (2018) Intracellular bacterial infections: a challenge for developing cellular mediated immunity vaccines for farmed fish. Microorganisms 6:33. https://doi.org/10.3390/microorganisms6020033

14. Sommerset I, Krossøy B, Biering E, Frost P (2005) Vaccines for fish in aquaculture. Expert Rev Vaccines 4:89-101. https://doi.org/10.1586/14760 584.4.1.89

15. Gudding R, Lillehaug A, Evensen O (1999) Recent developments in fish vaccinology. Vet Immunol Immunopathol 72:203-212. https://doi.org/10. 1016/s0165-2427(99)00133-6

16. Lastre M, Pérez O, Labrada A, Bidot I, Pérez J, Bracho G, del Campo J, Pérez D, Facenda E, Zayas C, Rodríguez C, Sierra G (2006) Bacterial derived proteoliposome for allergy vaccines. Vaccine 24:S34-S35. https://doi.org/ 10.1016/j.vaccine.2005.01.110

17. Acevedo R, Callicó A, del Campo J, González E, Cedré B, González L, Romeau B, Zayas C, Lastre M, Fernández S, Oliva R, García L, Pérez JL, Pérez O (2009) Intranasal administration of proteoliposome-derived cochleates from Vibrio cholerae $\mathrm{O} 1$ induce mucosal and systemic immune responses in mice. Methods 49:309-315. https://doi.org/10.1016/j.ymeth.2009.03. 027

18. del Campo J, Lastre M, Bracho G, RodríguezT, Gil D, Zayas C, Taboada C, Acevedo R, Pérez DR, Pérez O (2006) Immunological evaluation of bacterial derived Cochleate and proteoliposome as mucosal adjuvants. Vaccine 24:S50-S51

19. Rodríguez T, Pérez O, Ménager N, Ugrinovic S, Bracho G, Mastroeni P (2005) Interactions of proteoliposomes from serogroup B Neisseria meningitidis with bone marrow-derived dendritic cells and macrophages: adjuvant effects and antigen delivery. Vaccine 23:1312-1321. https://doi. org/10.1016/j.vaccine.2004.07.049

20. Pérez O, Lastre M, Lapinet J, Bracho G, Díaz M, Zayas C, Taboada C, Sierra $G$ (2001) Immune response induction and new effector mechanisms possibly involved in protection conferred by the Cuban anti-meningococcal $B C$ vaccine. Infect Immun 69:4502-4508. https://doi.org/10.1128/IAl.69.7. 4502-4508.2001

21. del Campo J, Zayas C, Romeu B, Acevedo R, González E, Bracho G, Cuello M, Cabrera O, Balboa J, Lastre M (2009) Mucosal immunization using proteoliposome and cochleate structures from Neisseria meningitidis serogroup B induce mucosal and systemic responses. Methods 49:301-308. https://doi.org/10.1016/j.ymeth.2009.03.025

22. Pérez O, Romeu B, Cabrera O, González E, Batista-Duharte A, Labrada A, Pérez R, Reyes L, Ramírez W, Sifontes S, Fernández N, Lastre M (2013) Adjuvants are key factors for the development of future vaccines: lessons from the finlay adjuvant platform. Front Immunol 4:407. https://doi.org/ 10.3389/fimmu.2013.00407

23. Pérez O, Lastre M, Cabrera O, del Campo J, Bracho G, Cuello M, Balboa J, Acevedo R, Zayas C, Gil D, Mora N, González D, Pérez R, González E, Barberá R, Fajardo EM, Sierra G, Solís RL, Campa C (2007) New vaccines require potent adjuvants like AFPL1 and AFCo1. Scand J Immunol 66:271-277. https://doi.org/10.1111/j.1365-3083.2007.01981.x

24. Nash RDM, Valencia AH, Geffen AJ (2006) The origin of Fulton's condition factor-setting the record straight. Fisheries 31:236-238

25. Midtlyng PJ, Reitan LJ, Speilberg L (1996) Experimental studies on the efficacy and side-effects of intraperitoneal vaccination of Atlantic salmon
(Salmo salar L.) against furunculosis. Fish Shellfish Immunol 6:335-350. https://doi.org/10.1006/FSIM.1996.0034

26. Karatas S, Mikalsen J, Steinum TM, Taksdal T, Bordevik M, Colquhoun DJ (2008) Real time PCR detection of Piscirickettsia salmonis from formalinfixed paraffin-embedded tissues. J Fish Dis 31:747-753. https://doi.org/ 10.1111/j.1365-2761.2008.00948.x

27. Brietzke A, Korytáŕ T, Jaros J, Köllner B, Goldammer T, Seyfert HM, Rebl A (2015) Aeromonas salmonicida infection only moderately regulates expression of factors contributing to toll-like receptor signaling but massively activates the cellular and humoral branches of innate immunity in rainbow trout (Oncorhynchus mykiss). J Immunol Res 2015:901015. https://doi.org/10.1155/2015/901015

28. Chettri JK, Raida MK, Kania PW, Buchmann K (2012) Differential immune response of rainbow trout (Oncorhynchus mykiss) at early developmental stages (larvae and fry) against the bacterial pathogen Yersinia ruckeri. Dev Comp Immunol 36:463-474. https://doi.org/10.1016/j.dci.2011.08.014

29. Skov J, Kania PW, Holten-Andersen L, Fouz B, Buchmann K (2012) Immunomodulatory effects of dietary $\beta$-1,3-glucan from Euglena gracilis in rainbow trout (Oncorhynchus mykiss) immersion vaccinated against Yersinia ruckeri. Fish Shellfish Immunol 33:111-120. https://doi.org/10. 1016/j.fsi.2012.04.009

30. Xuegin J, Kania PW, Buchmann K (2012) Comparative effects of four feed types on white spot disease susceptibility and skin immune parameters in rainbow trout, Oncorhynchus mykiss (Walbaum). J Fish Dis 35:127-135. https://doi.org/10.1111/j.1365-2761.2011.01329.x

31. Pfaffl MW (2001) A new mathematical model for relative quantification in real-time RT-PCR. Nucleic AcidsRes 29:e45

32. Rodríguez T, Pérez O, Ugrinovic S, Bracho G, Mastroeni P (2006) Bacterial derived proteoliposome as ideal delivery system and cellular adjuvant. Vaccine 24:S24-S25. https://doi.org/10.1016/j.vaccine.2005.01.106

33. Rickaby B, Eng NF, Flint A, Stintzi A, Diaz-Mitoma F (2015) The application of a proteoliposome adjuvant system in the development of a Campylobacter Jejuni vaccine. Procedia Vaccinol 9:38-43. https://doi.org/10.1016/j. provac.2015.05.007

34. Acevedo R, Callicó A, Aranguren Y, Zayas C, Valdés Y, Pérez O, García L, Valerie AF, Pérez JL (2013) Immune adjuvant effect of $V$. cholerae $O 1$ derived Proteoliposome coadministered by intranasal route with $\mathrm{Vi}$ polysaccharide from Salmonella Typhi. BMC Immunol 14:S10. https://doi. org/10.1186/1471-2172-14-S1-S10

35. Shaalan M, Saleh M, El-Mahdy M, El-Matbouli M (2015) Recent progress in applications of nanoparticles in fish medicine: a review. Nanomedicine 12:701-710. https://doi.org/10.1016/j.nano.2015.11.005

36. Rivas-Aravena A, Sandino AM, Spencer E (2013) Nanoparticles and microparticles of polymers and polysaccharides to administer fish vaccines. Biol Res 46:407-419. https://doi.org/10.4067/S0716-97602013000400012

37. Kole S, Qadiri SSN, Shin SM, Kim WS, Lee J, Jung SJ (2019) Nanoencapsulation of inactivated-viral vaccine using chitosan nanoparticles: evaluation of its protective efficacy and immune modulatory effects in olive flounder (Paralichthys olivaceus) against viral haemorrhagic septicaemia virus (VHSV) infection. Fish Shellfish Immunol 91:136-147. https://doi.org/10. 1016/j.fsi.2019.05.017

38. Bachmann MF, Jennings GT (2010) Vaccine delivery: a matter of size, geometry, kinetics and molecular patterns. Nat Rev Immunol 10:787-796. https://doi.org/10.1038/nri2868

39. Shah RR, O'Hagan DT, Amiji MM, Brito LA (2014) The impact of size on particulate vaccine adjuvants. Nanomedicine 9:2671-2681. https://doi. org/10.2217/nnm.14.193

40. Li J, Barreda DR, Zhang Y-A, Boshra H, Gelman AE, LaPatra S, Tort L, Sunyer OJ (2006) B lymphocytes from early vertebrates have potent phagocytic and microbicidal abilities. Nat Immunol 7:1116-1124. https://doi.org/10. 1038/ni1389

41. Folgueira I, Noia M, Blanco-Abad V, Mallo N, Leiro J, Lamas J (2015) Particle size and traffic of phagocytes between the turbot peritoneal cavity and lymphoid organs. Fish Shellfish Immunol 44:652-661. https://doi.org/10. 1016/j.fsi.2015.03.034

42. Zinkernagel RM (2000) Localization dose and time of antigens determine immune reactivity. Semin Immunol 12:163-171. https://doi.org/10.1006/ smim.2000.0253 (discussion 257-344)

43. Kastner E, Hussain MJ, Bramwell VW, Christensen D, Perrie Y (2015) Correlating liposomal adjuvant characteristics to in-vivo cell-mediated immunity using a novel Mycobacterium tuberculosis fusion protein: a 
multivariate analysis study. J Pharm Pharmacol 67:450-463. https://doi. org/10.1111/jphp.12390

44. Watson DS, Endsley AN, Huang L (2012) Design considerations for liposomal vaccines: influence of formulation parameters on antibody and cell-mediated immune responses to liposome associated antigens. Vaccine 30:2256-2272. https://doi.org/10.1016/j.vaccine.2012.01.070

45. Honary S, Zahir F (2013) Effect of zeta potential on the properties of nano-drug delivery systems - a review (Part 1). Trop J Pharm Res 12:255-264. https://doi.org/10.4314/tjpr.v12i2.19

46. Rigotti A, Acton SL, Krieger M (1995) The class B scavenger receptors SR-BI and CD36 are receptors for anionic phospholipids. J Biol Chem 270:16221-16224. https://doi.org/10.1074/jbc.270.27.16221

47. Torchilin VP (2005) Recent advances with liposomes as pharmaceutical carriers. Nat Rev Drug Discov 4:145-160

48. Ruyra A, Cano-Sarabia M, Mackenzie SA, Maspoch D, Roher N (2013) A novel liposome-based nanocarrier loaded with an LPS-dsRNA cocktail for fish innate immune system stimulation. PLoS One 8:e76338. https://doi. org/10.1371/journal.pone.0076338

49. Campbell F, Bos FL, Sieber S, Arias-Alpizar G, Koch BE, Huwyler J, Kros A, Bussmann J (2018) Directing nanoparticle biodistribution through evasion and exploitation of stab2-dependent nanoparticle uptake. ACS Nano 12:2138-2150. https://doi.org/10.1021/acsnano.7b06995

50. Berg A, Rødseth O, Tangerås A, Hansen T (2006) Time of vaccination influences development of adhesions, growth and spinal deformities in Atlantic salmon Salmo salar. Dis Aquat Organ 69:239-248. https://doi.org/ 10.3354/dao069239

51. Midtlyng PJ, Lillehaug A (1998) Growth of Atlantic salmon Salmo salar after intraperitoneal administration of vaccines containing adjuvants. Dis Aquat Organ 32:91-97. https://doi.org/10.3354/dao032091

52. Munang'andu HM, Fredriksen BN, Mutoloki S, Dalmo RA, Evensen O, (2013) The kinetics of CD4+ and CD8+ T-cell gene expression correlate with protection in Atlantic salmon (Salmo salar L) vaccinated against infectious pancreatic necrosis. Vaccine 31:1956-1963. https://doi.org/10 1016/j.vaccine.2013.02.008

53. Griffin BR (1983) Opsonic effect of rainbow trout (Salmo gairdneri) antibody on phagocytosis of Yersinia ruckeri by trout leukocytes. Dev Comp Immunol 7:253-259. https://doi.org/10.1016/0145-305X(83)90006-X

54. Ellis AE, Munroe ALS, Roberts RJ (1976) Defence mechanisms in fish. 1. A study of the phagocytic system and the fate of intraperitoneally injected particulate material in the plaice (Pleuronectes platessa L.). J Fish Biol 8:67-78. https://doi.org/10.1111/j.1095-8649.1976.tb03908.x

55. Evensen $\varnothing$ (2016) Immunization strategies against Piscirickettsia salmonis infections: review of vaccination approaches and modalities and their associated immune response profiles. Front Immunol 7:482. https://doi. org/10.3389/fimmu.2016.00482

56. Tobar I, Arancibia S, Torres C, Vera V, Soto P, Carrasco C, Alvarado M, Neira E, Arcos S, Tobar JA (2015) Successive oral immunizations against Piscirickettsia salmonis and infectious salmon anemia virus are required to maintain a long-term protection in farmed salmonids. Front Immunol 6:244. https://doi.org/10.3389/fimmu.2015.00244

57. Barraza F, Montero R, Wong-Benito V, Valenzuela H, Godoy-Guzmán C, Guzmán F, Köllner B, Wang T, Secombes C, Maisey K, Imarai M (2021) Revisiting the teleost thymus: current knowledge and future perspectives. Biology (Basel) 10:1-18. https://doi.org/10.3390/biology10010008

58. Nakanishi T, Shibasaki Y, Matsuura Y (2015) T cells in fish. Biology (Basel) 4:640-663

59. Fischer U, Utke K, Ototake M, Dijkstra JM, Köllner B (2003) Adaptive cellmediated cytotoxicity against allogeneic targets by CD8-positive lymphocytes of rainbow trout (Oncorhynchus mykiss). Dev Comp Immunol 27:323-337. https://doi.org/10.1016/S0145-305X(02)00100-3

60. Rozas-Serri M, Peña A, Maldonado L (2019) Gene expression associated with immune response in Atlantic salmon head-kidney vaccinated with inactivated whole-cell bacterin of Piscirickettsia salmonis and pathogenic isolates. Fish Shellfish Immunol 93:789-795. https://doi.org/10.1016/j.fsi. 2019.08.031

61. BirkbeckTH, Rennie S, Hunter D, Laidler LA, Wadsworth S (2004) Infectivity of a Scottish isolate of Piscirickettsia salmonis for Atlantic salmon Salmo salar and immune response of salmon to this agent. Dis Aquat Organ 60:97-103. https://doi.org/10.3354/dao060097

62. Kuzyk MA, Burian J, Thornton JC, Kay WW (2001) OspA, a lipoprotein antigen of the obligate intracellular bacterial pathogen Piscirickettsia salmonis. J Mol Microbiol Biotechnol 3:83-93

63. Salonius K, Siderakis C, MacKinnon AM, Griffiths SG (2005) Use of Arthrobacter davidanieli as a live vaccine against Renibacterium salmoninarum and Piscirickettsia salmonis in salmonids. Dev Biol 121:189-197

64. Miquel A, Müller I, Ferrer P, Valenzuela PDT, Burzio L (2003) Immunoresponse of Coho salmon immunized with a gene expression library from Piscirickettsia salmonis. Biol Res 36:313-323. https://doi.org/10.4067/ S0716-97602003000300004

65. Tobar JA, Jerez S, Caruffo M, Bravo C, Contreras F, Bucarey SA, Harel M, (2011) Oral vaccination of Atlantic salmon (Salmo salar) against salmonid rickettsial septicaemia. Vaccine 29:2336-2340. https://doi.org/10.1016/j. vaccine.2010.12.107

66. Wilhelm V, Soza C, Martínez R, Rosemblatt M, Burzio L, Valenzuela PDT (2005) Production and immune response of recombinant Hsp60 and Hsp70 from the salmon pathogen Piscirickettsia salmonis. Biol Res 38:69-82. https://doi.org/10.4067/s0716-97602005000100009

67. Smith PA, Contreras JR, Larenas JJ, Aguillon JC, Garces LH, Perez B, Fryer J (1997) Immunization with bacterial antigens: piscirickettsiosis. Dev Biol Stand 90:161-166

\section{Publisher's Note}

Springer Nature remains neutral with regard to jurisdictional claims in published maps and institutional affiliations.
Ready to submit your research? Choose BMC and benefit from:

- fast, convenient online submission

- thorough peer review by experienced researchers in your field

- rapid publication on acceptance

- support for research data, including large and complex data types

- gold Open Access which fosters wider collaboration and increased citations

- maximum visibility for your research: over $100 \mathrm{M}$ website views per year

At BMC, research is always in progress.

Learn more biomedcentral.com/submissions 